\title{
Survival Rate and Ultrastructure of Vitrified Bovine in vitro and in vivo Developed Embryos
}

\author{
By U. Darvelid ${ }^{l}$, H. Gustafsson ${ }^{2}$, M. Shamsuddin ${ }^{l}$, B. Larsson ${ }^{l}$ and H. Rodriguez Martinez ${ }^{l}$.
}

${ }^{1}$ Department of Obstetrics and Gynaecology, Faculty of Veterinary Medicine, Swedish University of Agricultural Sciences, Uppsala, and ${ }^{2}$ Swedish Association for Livestock Breeding and Production, Eskilstuna, Sweden.

\begin{abstract}
Darvelid, U., H. Gustafsson, M. Shamsuddin, B. Larsson and H. Rodriguez Martinez: Survival rate and ultrastructure of vitrified bovine in vitro and in vivo developed embryos. Acta vet. scand. 1994, 35, 417-426. - The capacity of different vitrification media and methods was tested onto in vivo and in vitro produced bovine morula/blastocysts and their ultrastructure and survival studied post-thawing. Two vitrification solutions were finally selected, named $40 \mathrm{ES}$ (40\% ethylene glycol in PBS containing $0.5 \mathrm{M}$ sucrose) and 35 EFS (composed of $35 \%$ (v/v) ethylene glycol in PBS containing $0.5 \mathrm{M} / \mathrm{l}$ sucrose and $30 \%$ (w/v) Ficoll 70 ). The straws were either precooled or not precooled in nitrogen vapour, plunged and stored in $\mathrm{LN}_{2}$ for 10-25 days, and then thawed in a $20^{\circ} \mathrm{C}$ waterbath. The content of the straws was rediluted in $1 \mathrm{M}$ sucrose solution in PBS and later cocultured with BOEC for $48 \mathrm{~h}$. The overall survival rates for in vitro and in vivo embryos were $36 \%$ (12 of 33 ) and $20 \%$ ( 3 of 15 ) after $24 \mathrm{~h}$ and $21 \%$ ( 7 of 33 ) and $33 \%$ ( 5 of 15 ) after $48 \mathrm{~h}$. The survival rates for precooled embryos were significantly higher than for not precooled ( $48 \%$ vs $13 \%$ after $24 \mathrm{~h}$ and $44 \%$ vs $4 \%$ after $48 \mathrm{~h}$ ) when tested across vitrification media. The in vitro-produced embryos presented an ultrastructure similar to the pre-freeze state, irrespective of the vitrification media used. The in vivo developed embryos showed a rather modified post-thaw ultrastructure, with clear signs of osmotic changes at both the trophoblastic and embryonic cells. The results indicated that in vitro and in vivo developed bovine embryos can survive vitrification using ethylene glycol as a cryoprotectant.
\end{abstract}

cryopreservation; vitrification; morphology.

\section{Introduction}

The first report on successful vitrification of mouse embryos (Rall \& Fahy 1985) indicated a possible alternative to freezing of livestock embryos. Shortly thereafter, Massip et al. (1986) established pregnancies following the transfer of vitrified bovine embryos. Since then, vitrification has also been applied to embryos from other farm species such as sheep and pig (Schiewe et al. 1991, Dobrinski 1993). Vitrification is defined as the physical process by which a highly concentrated solution of cryoprotectants solidifies during cooling without formation of ice crystals. The solution be- comes increasingly viscous and turn to an amorphous state called "glass", and retains the normal molecular and ionic distributions of the liquid state (Rall 1987). Several factors such as cooling rate, type of cryoprotectant, osmotic stress and sample volume seem to affect the survival rate of embryos following vitrification (Arav 1993). These factors are only to a minor extent analysed for in vivo-developed bovine embryos (Ishimori et al. 1993, Mahmoudzadeh et al 1993).

An advantage with vitrification is that mechanical damage to the embryo due to intraand extracellular ice formation does not oc- 
cur. An additional advantage is that freezing is accomplished by plunging the embryos into liquid nitrogen, thus eliminating the need for expensive controlled-rate cooling devices. Recently, pregnancies have been achieved by direct transfer to the recipient of bovine in vivo embryos which have been vitrified and where the cryoprotectant has been diluted within the straw (de Leeuw et al. 1991, de Leeuw et al. 1994, Ishimori et al. 1993). Vitrification in combination with one-step dilution simplifies and reduces the costs of freezing and thawing bovine embryos.

Data concerning survival following the vitrification of embryos produced by in vitro culture of oocytes matured and fertilized in vitro (in the following text referred to as IVMFCembryos) are very sparse. In one study, using a mixture of glycerol and 1,2-propandiol, high survival rates were obtained provided equilibration to cryoprotectants was made in at least 4 steps (Kuwayama et al. 1992). In another study, ethylene glycol and glycerol appeared less toxic than propyleneglycol following a 2 min exposure to IVMFC-embryos (Tachikawa et al. 1993). Dinnyés et al. (1994) achevied higher survival rates when blastocysts were vitrified in glycerol than in a mixture of ethylene glycol and Ficoll. The study also indicated that embryo age and quality affect post thaw survival.

In the present study, the vitrifying capacity of different vitrification media and the behaviour using different plunging methods was tested onto both in vivo and IVFMC bovine embryos. Furthermore, the fine structure and the postthaw-survival of IVMFC-blastocysts exposed to 2 different vitrification solutions were studied.

\section{Material and methods}

Production of blastocysts in vitro

Cumulus-oocyte complexes (COC) were col- lected from small ovarian follicles $(<7 \mathrm{~mm})$ at slaughter and cultured for maturation in TCM 199 (Earle's salt with glutamine and sodium bicarbonate, Bichrom, Berlin, Germany) supplemented with $10 \%(\mathrm{v} / \mathrm{v})$ oestrous cow serum (ECS) and $0.25 \mathrm{mmol} / 1$ sodium pyruvate (ECS medium; pH 7.4, 280-290 mOsm) according to the procedure described by Shamsuddin et al. (1993b). Following 24 to 25 $\mathrm{h}$ of culture, the expanded COC were inseminated with spermatozoa selected by a modified swim-up through a hyaluronic acid (HA; $1 \mathrm{mg} / \mathrm{ml}$ ) preparation (Shamsuddin \& Rodriguez-Martinez 1993). About 50000 selected spermatozoa were co-incubated with 10 to 15 COCs in a 50- $\mu$ l droplet of Fert-TALP medium (Parrish et al. 1988). After 20 to $22 \mathrm{~h}$ of co-incubation, the cumulus cells were removed from the presumptive zygotes by repeatedly passing them trough a small glass pipette. The zygotes were then transferred either to culture in a serum-free medium or to co-culture with bovine oviduct epithelial cells (BOEC).

A serum-free medium (SFM) was formulated by supplementing TCM 199 with BSA (10 $\mathrm{mg} / \mathrm{ml})$, insulin $(5 \mu \mathrm{g} / \mathrm{ml})$, transferrin $(5 \mu \mathrm{g} / \mathrm{ml})$, sodium selenite $(5 \mathrm{ng} / \mathrm{ml})$ and sodium pyruvate $(0.25 \mathrm{mM})(\mathrm{pH} \quad 7.4,280-290 \mathrm{mOsm}$, Shamsuddin et al. 1994). Bovine oviduct cells (BOEC) were prepared according to the procedure described by Shamsuddin et al. (1993a). Briefly, BOEC were collected by squeezing out the epithelial lining of an oviduct, washed 5 times in low bicarbonate TALP (Parrish et al. 1988), and cultured in ECS medium. After 24 to $48 \mathrm{~h}$ of culture, the cells were washed twice with the culture-medium by repeated centrifugation at $200 \mathrm{~g}$ for $10 \mathrm{~min}$, and the cell pellet was resuspended with the same medium at a ratio of 1:400. Droplets of the cell suspension were prepared under prewarmed $\left(30^{\circ} \mathrm{C}\right)$ paraffin oil and in- 
cubated overnight. Embryos were cultured in $50-\mu$ droplets at $39^{\circ} \mathrm{C}$ and $5 \% \mathrm{CO} 2$ in humidified air. In cases where co-culture was done together with BOEC, an additional 50- $\mu$ l ECS medium was added after $24 \mathrm{~h}$, to each drop. Embryos that had developed to blastocysts after 7 or 8 days of culture and with a good morphology were allocated for vitrification and test of survival after thawing. IVFMC-embryos of poorer quality were used to study overpressure in straws after thawing.

\section{Production of in vivo embryos}

Cows were superovulated with follicle stimulating hormone (Ovagen, Immuno-Chemical Products LTD, Auckland, New Zealand) and embryos were collected by methods as described previously (Albihn et al. 1989). Late morula- and blastocyst-stages of excellentgood quality (Lindner \& Wright 1983) were used in the experiment.

\section{Vitrification assay}

The basic medium for the vitrification solutions was PBS (Phosphate Buffered Saline, Swedish Veterinary Institute, Uppsala, Sweden) supplemented with $10 \%$ (v/v) FCS (Fetal Calf Serum, Swedish Veterinary Institute, Uppsala, Sweden), 0.5M sucrose (The Royal Veterinary and Agricultural University, Copenhagen, Denmark) and Kanamycin (25 $\mathrm{mg} / \mathrm{l}$, Sigma, St. Louis, USA). Decreasing (60$30 \%, \mathrm{v} / \mathrm{v})$ concentrations of ethylene glycol (EG) were tested to find the lowest concentration that allowed vitrification under cooling and thawing. Different macromolecules were thereafter added to the medium to study the possibility to decrease the EG concentration allowing vitrification. The macromolecules tested were Dextran T500, Ficoll 400, Ficoll 70 at 15 and $30 \%(w / v)$ and Hyaluronic acid $\left(\mathrm{Mw}=4.10^{6}\right)$ at $0.4 \%(\mathrm{v} / \mathrm{v})$ (Pharmacia, Uppsala, Sweden). The vitrification solutions were loaded in $0.25 \mathrm{ml}$ plastic straws (I.M.V., L'Aigle, France) in 2 columns separated by air bubbles. The straws were heat-sealed in the open end and closed with a plastic rod behind the factory plug in the other end. Within 20 sec the straws were progressively plunged into liquid nitrogen during approximatly $5 \mathrm{sec}$ onds. After storing in liquid nitrogen $\left(\mathrm{LN}_{2}\right)$ for 0.5 to $3 \mathrm{~h}$, the straws were thawed in a $20^{\circ} \mathrm{C}$ waterbath for aproximatly $15 \mathrm{sec}$ while visually inspected. Devitrification occuring during thawing was evident as whitening of the vitrification solution. A straw that appeared transparent both during vitrification and thawing was judged as successfully vitrified. Ten to 30 straws were tested for each solution. In preliminary trials, a high proportion (around 50\%) of vitrified straws exploded when thawed. Therefore, 2 methods of plunging the straws into $\mathrm{LN}_{2}$ were tested. Discarded IVMFC-embryos were equilibrated and loaded in straws as described below. Immediately after sealing, the straws were either directly but progressively plunged into $\mathrm{LN}_{2}$ or precooled for $1 \mathrm{~min}$ over the surface of $\mathrm{LN}_{2}$ in a thermos flask before plunging. The straws were thawed as described above. The number of exploded straws (high overpressure) and of straws from which the medium leaked out when opened (moderate overpressure) was also recorded.

\section{Vitrification and thawing}

Based on preliminary experiments, 2 vitrification solutions were selected for the present study. The solution named 40 ES was composed of $40 \%(\mathrm{v} / \mathrm{v})$ ethylene glycol in PBS containing $0.5 \mathrm{M}$ sucrose. The solution named 35 EFS consisted of $35 \%$ (v/v) ethylene glycol in PBS containing $0.5 \mathrm{M}$ sucrose and $30 \%$ (w/v) Ficoll 70, in the final concentration 19.3\% Ficoll and 0.33 M sucrose. 

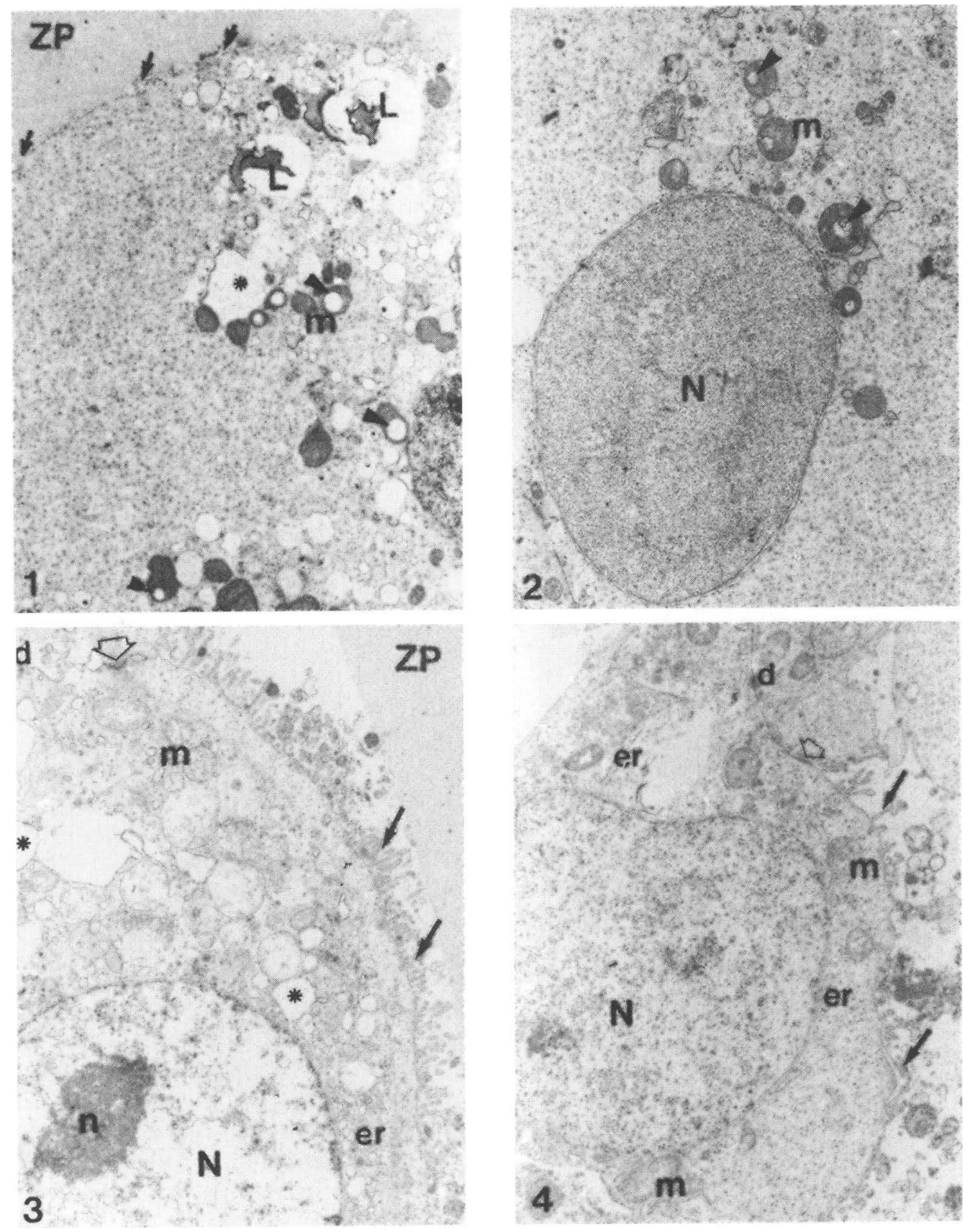

Figures 1-4: Transmission electron micrographs of in vivo (Fig. 1-2) and in vitro-developed (Fig. 3-4) bovine blastocysts thawed after vitrification in either 35 EFS (Fig. 1-3) or 40 ES (Fig. 2-4)(x7800). Note the few microvilli (arrows) towards the zona pellucida $(Z P)$ in the in vivo embryos (1-2). Most mitochondria $(m)$ appear spherical, with few cristae and with an electron-lucent area (arrowhead). Figures 3 and 4 show a much better preserved ultrastructure of the trophoblast, with numerous microvilli (arrows), mitochondria (m), short cell-tocell contacts (empty arrows, $d$ : desmosome), and organelles (*: vesicle, er: endoplasmic reticulum, $L$ : Lipid), $N$ : nucleus, n: nucleolus, $Z P$ : zona pellucida. 
In order to minimize the osmotic stress embryos to be vitrified in $40 \mathrm{ES}$ ( 20 and 28 in vivo and IVFMC embryos respectively) were equilibrated in PBS with increasing concentrations of ethylene glycol as follows; $10 \%$ for 3 $\min , 20 \%$ for $3 \mathrm{~min}, 30 \%$ for $2 \mathrm{~min}$ and $40 \%$ for $2 \mathrm{~min}$. Embryos to be vitrified in $35 \mathrm{EFS}$ (11 and 28 in vivo and IVFMC embryos respectively) were equilibrated in the solution in 1 step for $3 \mathrm{~min}$. During the equilibration in the final solution the embryos were placed into the straws by first aspirating a column (50 $\mathrm{mm}$ ) of medium $1 \mathrm{M}$ sucrose solution in PBS, a column $(30 \mathrm{~mm})$ with vitrification medium, a column $(3 \mathrm{~mm})$ with the embryo and of vitrification medium and a last column $(10 \mathrm{~mm})$ with vitrification medium. The columns were separated by air bubbles. The equilibration was carried out in petri dishes placed on ice blocks. The straws were sealed and plunged into $\mathrm{LN}_{2}$ as described above.

The straws were stored in $\mathrm{LN}_{2}$ for 10-25 days before thawing. Thawing was performed in a $20^{\circ} \mathrm{C}$ waterbath and the content of the straw was expelled into a petri dish containing $2 \mathrm{ml}$ $1 \mathrm{M}$ sucrose solution in PBS. After $5 \mathrm{~min}$ the embryo was transferred to pure PBS.

\section{Culture of thawed embryos}

After thawing, the embryos were washed twice in PBS, once in ECS medium and then cocultured with BOEC in 50- $\mu$ l droplets of ECS medium. The developmental stage of each embryo was considered and scored after $24 \mathrm{~h}$ and $48 \mathrm{~h}$, as $1=$ degenerated, collapsed with no signs of reexpansion, 2 = blastocysts, 3 $=$ expanded blastocyst, $4=$ hatched blastocyst.

\section{Electron microscopy}

Both in vivo embryos and IVMFC-embryos were also processed for transmission electron microscopy following vitrification-thawing in the 2 vitrification media. The embryos $(n=2$ - 3/group, total 20) were fixed in a 3\% solution of glutaraldehyde in $0.067 \mathrm{M}$ cacodylate buffer ( $\mathrm{pH} 7.2-7.4,480-500 \mathrm{mOsm})$ at $4^{\circ} \mathrm{C}$ at least overnight, postfixed with osmium tetroxide (1\%), dehydrated and embedded in Agar $100^{\mathrm{R}}$ plastic resin (Agar Aids, Essex, England). Serial semithin $(1 \mu \mathrm{m})$ and ultrathin sections $(60 \mathrm{~nm})$ were cut with an Ultrotome ${ }^{\mathrm{R}}$ (LKB, Stockholm, Sweden). The semithin sections were stained with buffered toluidine blue and examined under a light microscope for selection of further sectioning. Ultrathin sections were picked-up on copper grids, counterstained with uranyl acetate and lead citrate, and examined on a Philips EM 420 electron microscope at $60-80 \mathrm{Kv}$.

\section{Statistics}

Data were analysed by $\mathrm{X}^{2}$ test or by Fishers test when the number of observations was less than 5 .

\section{Results \\ Vitrification assay}

A solution with $40 \%(\mathrm{v} / \mathrm{v})$ of ethylene glycol in PBS allowed vitrification while a solution with $37.5 \%(\mathrm{v} / \mathrm{v})$ did not. After addition of the macromolecules Dextran T500, Ficoll 70 or Ficoll 400 at $15 \%$ (w/v), a solution with $37.5 \%$ (v/v) of ethylene glycol allowed vitrification. When the concentration of macromolecules was increased to $30 \%(\mathrm{w} / \mathrm{v})$ it was possible to decrease the concentration of ethylene glycol to $35 \%(\mathrm{v} / \mathrm{v})$. The solution with Dextran T500 had a high viscosity and was therefore less suitable. The addition of Hyaluronic acid decreased the vitrification ability.

All embryos showed signs of heavy shrinkage when equilibration in 35 EFS medium was made in 1 step. Such osmotic effects occurred as well onto embryos equilibrated in 40-ES medium, although less pronounced. 
Table 1. Number of straws (\%) with overpressure during thawing.

\begin{tabular}{lllll}
\hline Treatment & $\mathrm{n}$ & \multicolumn{3}{c}{ Overpressure } \\
\cline { 3 - 5 } & & High $^{1}$ & Moderate $^{2}$ & No \\
\hline Precooled & 52 & $5(10 \%)$ & $10(19 \%)$ & $37(71 \%)^{\mathrm{a}}$ \\
Not Precooled & 73 & $20(27 \%)$ & $19(26 \%)$ & $34(47 \%)^{\mathrm{b}}$ \\
\hline
\end{tabular}

${ }^{\text {ab }} \mathrm{p}<0.05$

${ }^{1}$ Straws exploding when thawing.

${ }_{,}^{2}$ Content leaking out when opening the straw.

The effect of precooling of the straws upon the occurrence of overpressure in the straws during thawing is shown in Table 1 . The proportion of straws with overpressure was significantly reduced $(\mathrm{p}<0.05)$ when the straws were precooled before plunging into $\mathrm{LN}_{2}$.

\section{Post-thaw survival}

The post-thaw survival rates for in vitro and in vivo embryos in the different treatment groups are shown in Table 2. Both IVMFC and in vivo embryos survived vitrification essentially in the same manner. However, any comparison between the 2 groups could not be made due to the low number of embryos and therefore, for the statistical analysis, the in vivo and IVFMC embryos were pooled. When comparing both vitrification media across plunging methods there were no significant differences in survival rates. The survival rates for precooled embryos were significantly higher than for not precooled $(48 \%$ vs $13 \%$ after $24 \mathrm{~h}$ and $44 \%$ vs $4 \%$ after $48 \mathrm{~h}$, $\mathrm{p}<0.01$ ) when tested across vitrification media.

\section{Electron microscopy}

The post-thaw ultrastructure of the in vivo embryos vitrified in either $35 \mathrm{EFS}$ or $40 \mathrm{ES}$ appeared rather modified (Fig. 1 and 2). They presented signs of osmotic changes at both the trophoblastic and embryonic cells, with enlarged, spherical cells. The trophoblast presented fewer short microvilli than what is seen in the precool state. The nuclei, centrally-located, were homogeneous with mostly euchromatin and distorted nucleoli. Few organelles were visible. Of these, mitochondria were the most numerous, although they were spherical, with few or no cristae, and many of them presenting an empty or electron-lucent vesicle-like space inside. Cell-to-cell contacts were present, anchoring the cells together. Few lipid droplets were seen. No major differences were seen between the vitrification media used.

The IVFMC embryos, following vitrification and thawing, presented a much better ultrastructure, irrespective of the vitrification media used (Fig. 3-4). The trophoblast consisted of somewhat flattened, though well polarized cells which surrounded the blastocoele. The nuclei were also flattened and showed well developed nucleoli. The amount of microvilli at the apical membrane was conspicuous (Fig. 3-4). The cytoplasm was more electrondense than the in vivo embryos and presented a very well-developed cytoskeleton. Mitochondria were abundant, round to elongated and with transverse cristae (Fig. 4). Many membrane profiles of endoplasmic reticulum and vesicles of various sizes were commonly seen in the cy- 
Table 2. Survival rates after in vitro culture of thawed IVMFC - and in vivo embryos vitrified in 2 different solutions and according to 2 plunging methods.

\begin{tabular}{lllll}
\hline Treatment & $\begin{array}{l}\text { No of } \\
\text { straws } \\
\text { thawed }\end{array}$ & $\begin{array}{l}\text { No of } \\
\text { embryos } \\
\text { recov. }\end{array}$ & $\begin{array}{l}\text { Numbers (\%) of } \\
\text { embryos } \\
\text { survived 24 h. }\end{array}$ & $\begin{array}{l}\text { No (\%) of embr. } \\
\text { in perihatching } \\
\text { stage 48 h. }\end{array}$ \\
\hline $\begin{array}{l}\text { IVMFC-embryos } \\
\text { 40 ES }\end{array}$ & 15 & 9 & $1(11)$ & $1(11)$ \\
35 EFS & 13 & 7 & $2(29)$ & 0 \\
Precool 40 ES & 9 & 7 & $3(43)$ & $3(43)$ \\
Precool 35 EFS & 11 & 10 & $6(60)$ & $3(30)$ \\
In-vivo embryos & & & & \\
40 ES & 7 & 6 & 0 & 0 \\
35 EFS & 1 & 1 & 0 & 0 \\
Precool 40 ES & 7 & 5 & $2(40)$ & $4(80)$ \\
Precool 35 EFS & 4 & 3 & $1(33)$ & $1(33)$ \\
\hline
\end{tabular}

Treatments are defined in material and methods.

toplasm. Lipid droplets were also present. The trophoblastic cells were anchored to each other by cell-to-cell contacts at the lateral plasmalemmae (Fig. 3). Large intercellular spaces were common among the cells. The embryonic cells were polyhedral and separated by wide intercellular spaces. They had a spherical nucleus with well developed nucleoli and a cytoplasm which was somewhat more electron-dense and homogeneous than the trophoblast.

\section{Discussion}

In spite of the limited number of embryos tested, our results clearly indicate that bovine embryos can survive vitrification using ethylene glycol as a cryoprotectant. The survival rate after vitrification was higher than the survival rates around $30 \%$ obtained in our laboratory after freezing of IVFMC embryos with standard methods (Gustafsson et al., unpublished data). This is an interesting indication since in vitro produced embryos are generally regarded to be more sensitive to freezingthawing than in vivo embryos (Larsson et al. 1992, Greve et al. 1993, Leibo \& Loskutoff 1993).

The large amount of lipidic deposits in the cytoplasm (Shamsuddin et al. 1992, Leibo \& Loskutoff 1993), the shortage of trophoblast microvilli and the poorly developed cell-tocell contacts between trophoblast cells and/or cells of the inner cell mass (Shamsuddin et al. 1992) are among the causes for increased sensitivity to conventional cryopreservation procedures (i.e.using glycerol as coprotectant) by in vitro-developed embryos (Mohr \& Trounson 1981).

Whether or not the use of other cryoprotectants and/or different (i.e. ultrarapid) cooling rates is responsible for the improvement in the results when vitrifying in vitro-developed embryos is yet unknown. Neither is it easy to explain the differences obtained in the 
present study between in vitro and in vivo embryos. One might speculate that the fact that the in vivo embryos beeing most morula stages and the IVFMC embryos beeing blastocyst stages affected the post thaw survival rates. Effects of embryo age and developing stage on post-thaw survival after vitrification have been suggested by Dinnyés et al. (1994). In our earlier studies, up to $50 \%$ of the straws exploded when thawed, thus leading in most cases to loss of embryos. The preecooling of the straws in nitrogen vapour before plunging into $\mathrm{LN}_{2}$ significantly reduced fracturing of the straws, confirming previous reports (Rall et al. 1987). On the other hand, preecooling changes the cooling rate during vitrification and might in itself be harmful to the cells. However, in our study significantly more embryos survived when precooling was applied, thus indicating this was more harmless as a vitrification process.

In agreement with MacFarlane (1987), our vitrification assay showed that a concentration of $>40 \%$ of the cryoprotectant allows vitrification. Addition of a non-penetrating agent such as Ficoll is known to increase the probability of vitrification, allowing a reduction in concentration of the cryoprotectant (ethylene glycol), as shown in the present study. This would in turn reduce both toxic and osmotic effects of the vitrification solution. However, the viscosity of the solution increases by addition of these macromolecules, which impairs handling of the embryos.

Ethylene glycol is a highly permeable cryoprotectant to embryos which in turn causes less osmotic effects. Nevertheless osmotic distortion of the blastocysts was observed when equilibration in $35 \mathrm{EFS}$ medium was made in 1 step. An osmotic effect onto embryos equilibrated in 40-ES medium occurred as well, although it appeared to be less pronounced. The osmotic effect observed however, seemed not to affect the embryo survival since no significant differences in survival rates were observed between the 2 vitrification media. On the other hand, Kuwayama et al. (1992) used a mixture of glycerol and 1,2-propanediol as cryoprotectant and obtained higher survival rates when the embryos were equilibrated in 4 steps or more compared to less than 4 steps, clearly indicating that osmotic injury is lethal to embryos.

In summary, the present preliminary results clearly indicate that vitrification is possible onto in vitro-developed bovine embryos, allowing a certain degree of survival and further development. However, the discrepancies seen between the in vitro and in vivo-developed embryos in their degree of ultrastructural damage and survival ability after thawing remain unexplained and motivate further studies in these matters.

\section{Acknowledgements}

We thank Ms A. Colbring for her assistance in the IVF laboratory and Mrs M. Ekwall and Mr H. Ekwall for their expert assistance with the electron microscopy. The present study was supported by the Swedish Council for Forestry and Agricultural Research.

\section{References}

Albihn A, Gustafsson H, Rodriguez-Martinez $H$, Larsson $K$ : Development of day 7 bovine demiembryos transferred into virgin and repeatbreeder heifers. Anim. Reprod. Sci. 1989, 21, 161-176.

Arav A: Vitrification of oocytes and embryos. In: Lauria S, Gandolti F. (eds.): Embryonic development and manipulation in animal production. Portland Press, London and Chapel Hill 1993, 255-264.

De Leeuw AM, Rall WF, den Daas JHG, Kruip AM: Comparative studies of the efficacy of rapid cryopreservation methods for bovine embryos. 7th Sci. Meet. A.E.T.E., Cambridge 1991, 77-86.

Dinnyés A, Keefer $C L$, Stice SL, Solti L, Vajta G, Macháty $Z$, Rall WF: Vitrification of IVFMC bo- 
vine embryos in VS3a and EFS solutions: A preliminry report. Theriogenology 1994, 41, 189.

Dobrinsky JR: Cryopreservation of porcine embryos: Current status and perspectives. Embryo transfer newsletter 1993, 11, 13-18.

Greve $T$, Avery $B$, Callesen $H$ : Viability of in-vivo and in-vitro produced bovine embryos. Reprod. Dom. Anim. 1993, 28, 164-169.

Ishimori H, Saeki K, Inai M, Nagao Y, Itasaka J, Miki $Y$, Seike N, Kainuma $H$ : Vitrification of bovine embryos in a mixture of ethylene glycol and dimethyl sulfoxide. Theriogenology 1993, 40, 427-433.

Kuwayama M, Hamano S, Nagai T: Vitrification of bovine blastocysts obtained by in vitro culture of oocytes matured and fertilized in vitro. J. Reprod. Fert. 1992, 96, 187-193.

Larsson B, Shamsuddin M, Gustafsson H: Post-thaw viability of bovine embryos obtained in vitro. Proc 12th Int Congr Anim Reprod, The Hague, The Netherlands 1992, 3, 1451-1453.

Leibo SP, Loskutoff NM: Cryobiology of in vitro-derived bovine embryos. Theriogenology 1993, 39, 81-94.

Lindner GM, Wright RW Jr: Bovine embryo morphology and evaluation. Theriogenology 1983, 20, 407-416.

MacFarlane DR: Physical aspects of vitrification in aqueous solutions. Cryobiology 1987, 24, 181195.

Mahmoudzadeh AR, Van Soom A, Van Vlaenderen I, De Kruif A: A comparative study of the effect of one-step addition of different vitrification solutions on in vitro survival of vitrified bovine embryos. Theriogenology 1993, 39, 1291-1302.

Massip A, Van der Zwalmen P, Ectors F: Pregnancies following transfer of cattle embryos preserved by vitrification. Cryo-Letters 1986, 9, 270-273.

Mohr LR, Trounson AO: Structural changes associated with freezing of bovine embryos. Biol. Reprod. 1981, 25, 1009-1025.

Parrish JJ, Susko-Parrish J, Winer MA, First NL: Capacitation of bovine sperm by heparin. Biol. Reprod. 1988, 38, 1171-1180.

Rall WF: Factors affecting the survival of mouse embryos preserved by vitrification. Cryobiology 1987, 24, 387-402.

Rall WF, Fahy GM: Ice-free cryopreservation of mouse embryos at $-196^{\circ} \mathrm{C}$ by vitrification. Nature 1985, 313, 573-575.

Rall WF, Wood MJ, Kirby C, Whittingham DT: Development of mouse embryos cryopreserved by vitrification. J. Reprod. Fert. 1987, 80, 499-504.

Schiewe MC, Rall WF, Stuart LD, Wildt DE: Analysis of cryoprotectant, cooling rate and in situ dilution using convetional freezing or vitrification for cryopreservation of sheep embryos. Theriogenology 1991, 36, 279-293.

Shamsuddin M, Rodriguez-Martinez H: A simple, non-traumatic swim-up method for the selection of spermatozoa for in vitro fertilization in the bovine. Anim. Reprod. Sci. In Press.

Shamsuddin M, Larsson B, Gustafsson H, Gustari S, Bartolome J, Rodriguez-Martinez H: Comparative morphological evaluation of in vivo and in vitro produced bovine embryos. Proc 12th Int Congr Anim Reprod, The Hague, The Netherlands 1992, 3, 1333-1335.

Shamsuddin M, Larsson B, Gustafsson H, Rodriguez-Martinez $H$ : In vitro development up to hatching of bovine in vitro matured and fertilized oocytes with or without support from somatic cells. Theriogenology 1993a, 39, 10671079.

Shamsuddin M, Larsson B, Rodriguez-Martinez $H$ : Maturation-related changes in bovine oocytes under different culture conditions. Anim. Reprod. Sci. 1993b, 31, 49-60.

Shamsuddin M, Larsson B, Gustafsson H, Rodriguez-Martinez $H$ : A serum-free, cell-free culture system for development of bovine one-cell embryos up to blastocyst stage with improved viability. Theriogenology, 1994, 41, 1033-1043.

Tachikawa S, Otol T, Kondo S, Machida T, Kasai M: Successful vitrification of bovine blastocysts, derived by in vitro maturation and fertilization. Molec. Reprod. Develop. 1993, 34, 266-271.

van Wagtendonk-de Leeuw AM, den Daas JHG, Rall $W F$ : Pregnancy rates in a comparative field trial of vitrification and one-step dilution or conventional slow freezing and three-step dilution of bovine embryos are similar. Theriogenology, 1994, 41, 326.

\section{Sammanfattning}

Överlevnadsprocent och ultrastruktur hos vitrifierade in vitro och in vivo embryon från nötkreatur.

Olika mediers förmåga till vitrifiering testades på in vivo och in vitro producerde embryon och ultrastruktur och överlevnadsförmåga studerades efter tining. Baserat på inledande försök valdes 2 vitrifieringsmedier för fortsatta studier; $40 \mathrm{ES} \mathrm{(40 \%} \mathrm{v/v}$ ethylene glycol i PBS mad $0.5 \mathrm{M}$ sucrose) och $35 \mathrm{EFS}$ 
(35\% v/v ethylene glycol i PBS med $0.5 \mathrm{M}$ sucrose och $30 \%$ (w/v) Ficoll 70). Embryon equilibrerades i respektive medium och aspirerades $\mathrm{i}$ strån vilka kyldes eller ej kyldes under en minut i kväveånga innan de fördes ned i flytande kväve. Stråna tinades $i$ vattenbad $\left(+20^{\circ}\right)$ och vitrifieringsmediet späddes bort i PBS med 1M sackaros. Embryona odlades in vitro med BOEC varefter utvecklingsgraden utvärderades efter 24 och 48 timmar. Både in vivo och in vitro embryon överlevde vitrifiering i huvudsak $i$ samma omfattning. Överlevnadgraden hos embryon som kyldes över kväveånga innan de fördes ned i flytande kväve var högre än hos embryon som direkt fördes ned i kväve (48\% jämfört med 13\% efter 24 timmar och $44 \%$ jämfört med $4 \%$ efter 48 timmar) oavsett medium. Efter frysning och tining hade in vitro producerade embryon en bättre ultrastruktur än in vivo embryon. De senare uppvisade klara tecken på osmotiska förändringar hos både trofoblast- och embryonalceller. Resultaten visar klart att in vitro embryon kan överleva vitrifiering med ethylenglykol som vitrifieringsmedium.

(Received May 9, 1994; accepted September 8, 1994).

Reprints may be requested from: H. Gustafsson, Department of Obstetrics and Gynaecology, Faculty of Veterinary Medicine, Swedish University of Agricultural Sciences, P. O. Box 7039, S-75007 Uppsala, Sweden. 